\title{
An Investigation of Alternative Assessment for writing skill in second semester of Industrial Engineering at University of Muhammadiyah Gresik
}

\author{
Dwi Masyithah Rizqiyah \& Candra Hadi Asmara \\ University of Muhammadiyah Gresik \\ Jl. Sumatra No. 101 GKB Gresik \\ E-mail : candrafkip@umg.ac.id
}

Received: July 10, 2017

Accepted: August 17, 2017

Published: August 31, 2017

\begin{abstract}
Assessment has various types in education program. Even, it was as one of aspect in determining the students' skill. Additionally, one skill which is as the last skill in language acquisition is writing. Since it is the last, means it is difficult to be learnt moreover to be assessed. When writing is difficult to be assessed, the teacher has to know and understand various type of assessment for writing. This study was conducted to describe types of alternative assessment for writing skill in $2^{\text {nd }}$ semester of Industrial Engineering at University of Muhammadiyah Gresik in academic year of 2016/2017 and also to describe implementation of Alternative Assessment for writing skill in second semester of Industrial Engineering at University of Muhammadiyah Gresik which used descriptive qualitative. There were two lecturers of D1 English Language at UMG who were as the subject of this study which were selected by questioners about the alternative assessment for writing skill. The data collected by observation in $\mathrm{K}$ and L classes of Industrial Engineering Department. Additionally, the interview was done with two lecturers and some students. The finding of this study showed that two lecturers applied alternative assessment with same type. Those were writing sample, conference, and teacher- feedback. Furthermore, the implementation of alternative assessment in writing skill was done by asking and drill the students in composing writing to make them comprehend about writing composition and be more confident for composing writing. After they comprehended then they could compose full text. When the students practice in writing, the lecturer guided them by discussing face to face or in whole class. The feedback had to be given to develop the students' motivation in writing. When the motivation was high then the students could improve their writing composition and help the students to revise their writing' work. It can be concluded that alternative assessment for writing skill which have been applied are writing sample, conference, and teacher-feedback. The writing sample uses as the practice by composing sentence then compose text to know the progress. The conference can be held in face to face with lecturer and with whole class. Additionally, the feedback can be given during activity and after activity in spoken and written by directly or indirectly. The researcher suggests the further researcher to conduct at another level. The researcher hopes that there will be further research on the implementation of alternative assessment for writing skill in different field or study with different subject and different focus.
\end{abstract}

Keywords: Alternative Assessment for writing skill, Writing Sample, Conference, Teacher-feedback

\section{Introduction}

Various assessments have been applied by the teacher to evaluate the students' ability in order to achieve the learning aim which helps the learners for their learning process in education field. As Nodoushan (2004) stated that the assessment supports the learning and develops the students' learning. Additionally, according to Nasri (2010) said that assessment can help the education quality because lifelong learning skills and performance in any educational context can be improved. Therefore, the teachers apply assessment in different ways such as portfolio assessment, formative assessment, self- assessment, traditional assessment, and etc. One of assessment is portfolio assessment which lets the teacher to gather the students' assignment. According to Samad (2012) portfolio assessment is as a collection of students' work which is going to be analyzed by the teachers. It means that the teachers need to collect students' work over a period of time in order to know students' skill progression. Additionally, portfolio can help the learners to be more independent in their learning. In the same line, Tabatataei (2012) told that the main goal of portfolio is to make the learners be autonomous in making decision, able to do self-assessment and becoming active learners. 
Another assessment is self-assessment. As the name which is self- assessment, it refers to assess students' work by the students themselves. The learners are not only able to assess their work but also able to reflect in order to enhance their skills. According to Harris (1997) self-assessment can boost the students to be more active in their learning.

Even though the teachers use different kind of assessment which are stated by some theories, but not all assessments are match with the students. Because the students have different level of ability. Furthermore, the implement of assessment is not as the recommendation by the specialist or handbook or we can say the assessment approach which is recommended by the specialist sometimes different with the implementation. In the same line, Milnes and Cheng, (2008) said that there is a divergence of approaches which are recommended and those essentially carried out by classroom teachers.

Although there are four skills in learning English which have to be assessed, but here one of skill in English learning which is discussed is writing skill. As the productive skill, writing is not easy to be achieved because the learners have to produce written product. This skill is the most difficult ability to teach and assess. As Nodoushan (2014) writing skill is the most tough language ability to teach, and even to assess.

The teacher needs to design the appropriate writing assessment for the students. The authentic situation is necessary to be built during teaching learning process. Even the assessment is based on the authentic condition too. In the same line, Bennett and Gitomer (2009) argued that teachers should develop assessment structures as document what students have completed, help recognize how to plan teaching, and turn the testing condition into a meaningful educational experience.

In order to give proper task to the students, the teacher needs to know and understand some kind of writing assessment. The teachers need to increase their knowledge about various assessment which can interest their students. In line with Kroll (1990) states that raising useful and effective language students' skills is an accurate task when the teacher lacks of experience and fails to provide right practice. At what time it comes to writing, the teacher's work is even more difficult. Improving writing requires the teachers' use of authentic tasks, organized lessons, and real-life experiences (Nodoushan, 2014).

The goal of language learning is to develop the students' skills, it means the teachers have to assess students' skill in proper way systematically. According to Linn and Miller (2005) defines assessment as a systematic procedure of collecting information about students' progress to the learning goals. Similarly, Dhindsa et al. (2007) states that assessment is a key teaching component and learning, "an organized process of data collecting" about students' improvement. Another assessment which has been existed for many years ago is paper-pen assessment which is as traditional assessment. As in the national examination, the government implements multiple choice to measure students' skill. Yancey (1999) notes that in the 1950s and 1960s there were many writing assessments conducted by using multiple choice tests of grammar, usage and mechanics. Although it is traditional, but many educators still implement it in writing class. In other hand, alternative assessment, it defines as the assessment method which is used to be alternative to traditional assessment in order to assess students' ability. According to Lopes (2015) defines alternative assessment as any assessment method which is an alternate to the traditional tests. Additionally, Puhl (1997) states that alternative assessments let students to establish their understanding and own meaning of what they have learnt in the class.

Additionally, the alternative assessment have a number of advantages. Such as Lopes (2015) states that alternative assessment gives benefits in allowing the students to be assess every day in classroom, providing the students' weakness and strengths, multicultural complex when properly managed, and extending the day-to-day in the classroom activities as in the placement of the curriculum. Getting alternative assessment, the learners can correct their ability every meeting since the teacher provides their strengths and weakness. Furthermore, there is a research about different kind of writing assessment which was conducted by Ketabi (2016). It discusses about the methods of assessing writing in Iranian EFL classes. The study shows that most frequent methods among teachers of adult and young learners were writing essays and dictation respectively.

Based on the explanation above, assessment for writing skill has various ways. Additionally, writing skill suitable to be applied for alternative assessment than traditional assessment. According to Assessment, Accuration and Accountability described that traditional assessment such as paper pencil test is useful for receptive skill. It means that alternative assessment is useful for productive skill such as writing (Anwar \& Arifani, 2016; Anwar, 2016 a; Anwar, 2016 b; Asmara, Anwar, \& Muhammad, 2016).

Furthermore, primary study was done by giving questioners to the lecturer of D1 English language at UMG. Among total lecturer which are 12, the 10 lecturers have filled the questioners. The result shows that all lecturers have applied alternative assessment in different types. However, the limited time is considered, so industrial engineering which has two lecturers is chosen to be the subject of this study. In sum, the researcher is interested to conduct research which its aim is to know kind of alternative assessment activity which apply by teacher, to describe types of alternative assessment for writing skill implemented in second semester of Industrial Engineering at UMG and to describe implementation of Alternative Assessment writing skill in second semester of Industrial Engineering at UMG. 


\section{Methods}

This research investigates the alternative writing assessment in the Industrial Engineering at UMG. Additionally, according to Harwell (2011) qualitative methods uses to construct a theory from the detail provided by the participant. This study tries to find the types of alternative assessment for writing skill and to find the implementation of alternative writing assessment for writing skill in Industrial Engineering at UMG. Furthermore, the goal of this research is not to calculate how many lecturer use alternative assessment strategy in writing skill.

\section{Subject of the Study}

The subject of this study is the lectures of D1 English language at UMG. The preliminary study was conducted by giving questioners to the lecturers of D1 English Language at UMG which is total 12 lecturers. The questionnaire is focused on the types of alternative assessment for writing skill. Out of 12 lecturers, there are 10 lecturers who have answered the questionnaire. The questioners result shows that all 10 lecturers have applied alternative assessment with different way. However, among 10 lecturers, the researcher chooses two lecturers who have high score. It means that they have applied alternative assessment in writing skill more than other lecturers. The two lecturers teach Industrial Engineering which consist of two classes which are K class and L class.

\section{Research Instrument}

There are two main instruments for this study which are observation and interview. The instruments are used to collect the data which related to this study. The first is observation is conducted in the second semester of industrial engineering writing class about the implementation of alternative assessment for Writing in that class and alternative assessment activity in writing class. The second instrument is interview which is done for knowing unclear data from observation which cannot be seen from it. Furthermore, the researcher acts as planners, implementers, data collectors, analyzer, interpretation of data, up to the stage of reporting research results.

The observation is companied by video recording. Additionally, there is observation form to analyze the implementation of alternative assessment in writing. The observation form is adapted from Ercilia (2016). It consist of some types of alternative assessment which are portfolio, writing sample, conference, summarizing, reflective writing, teacherfeedback, pair-feedback, and self- assessment. Those types be compost some characteristics.

The next instrument is interview with the lecturer. It is companied by audio recording. The interview is about the information which cannot be seen from observation. The interview is semi-structured interview which lets the researcher explorers more related to implementation of alternative assessment.

\section{Data Collection Procedures}

Several techniques will be used to gather data for this research. Those techniques are observation and interview which are applied in order to gain information about the alternative assessment for writing skill implemented by the lecturer in second semester of Industrial Engineering. As stated by Ary, et.al (2010) that there are three most common data collection method which are observation, interview, and document or artifice analysis. In addition, data collection can be stopped when the data have answer all the research problem in this study. The following is the procedure for collecting data:

\section{Observation}

The first data collection is done by observation which is in the industrial engineering class at UMG. The total meeting in industrial class for writing skill is 15 meetings but the meeting depends on the students' need which can be less than 15 meetings. Furthermore for this research, the observation will be around six times in two classes of industrial engineering which are $\mathrm{K}$ class and $\mathrm{L}$ class. Each class consist of three meetings.

The observation is focus on the lecturers' teaching which implement alternative assessment for writing skill. As Ary, et. Al (2010) stated that qualitative study focused on describing the setting, behavior, and interaction. Furthermore, the observation will use video recording to record the implementation of alternative assessment in the classroom.

\section{Procedures for Conducting Interview}

The interview will be conducted after the observation finished in order to confirm the result of observation or the unsure activity during apply alternative assessment. Based on Ary, et. $\mathrm{Al}$ (2010) interview is used to collect data about opinions, beliefs, and feelings from people about situations in their own words.

Audio recording is companied as a tool to prevent losing any specific information. The researcher will also take a note during the interview to write some information which can be used to give for next questions 
In addition, semi-structured interview is used. Before conducting the interview, the researcher lists some questions. Then, during the interview, the researcher asks detail questions which related to the previous question. Those questions have relation with the implementation of alternative assessment which have been done by the lecturers.

Technique of Data Analysis

The next step of this study is data analysis which the goal is to analyses the collected data. After finishing in collecting data, the researcher immediately analyses the data because it can be time consuming since the qualitative research has many data. This research analyses data by using three process which are reduction, displaying, and drawing conclusion. According to Miles and Huberman (1994) described that data analysis consist three processes which are data reduction, data display, and drawing conclusion.

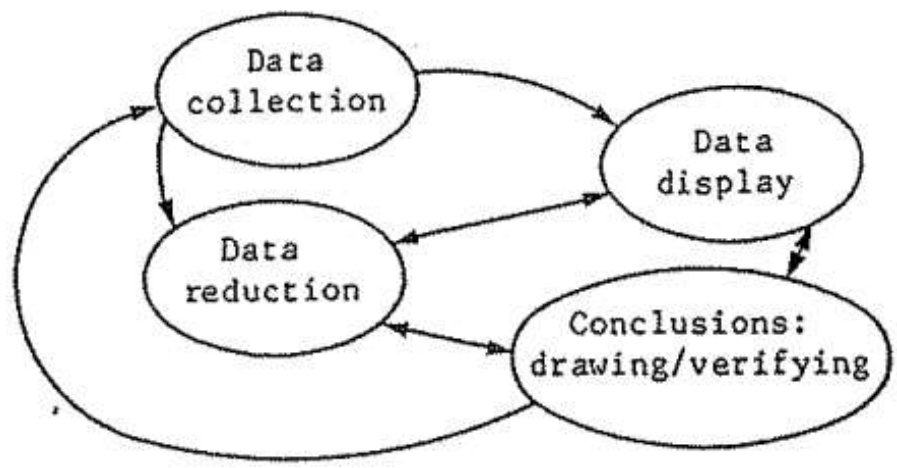

Figure 1. Components of Data Analysis: Interactive Model by Miles and Hubeman (1994)

\section{Data Reduction}

This process allows the researcher to reduce the data collection which does not have any connection with the implementation of alternative assessment. The reduction is done in order to focus with the issue have risen in this study. According to Miles and Huberman (1994) stated that data reduction relate with the process of simplifying, selecting, abstracting the data from written field note or transcription. While the data reduction comes from observation transcription and recording in the writing class of industrial engineering at UMG Then, the data discards the activity and information which are unimportant with the focus of this study. Furthermore, the appropriate or important activity and information related to the implementation of alternative assessment is collected and kept.

Data Display

After reducing the data, the researcher displays important data and information with the focus of the study. The researcher displays data which is appropriate with the types of alternative assessment which have been applied and implementation of alternative assessment. Data display for this study is from the transcription and narration which are made by the researcher based on the writing class observation. Miles and Huberman (1994) said that data display is part of data analysis which is a process deciding related data should be entered in the cell or which related data should be display. Additionally, data display in this study is not only from writing class observation but also from interview with the lecturers of industrial engineering in second semester at UMG.

\section{Drawing Conclusion}

The last process in data analysis is drawing conclusion which analyses the data in order to obtain conclusion for the study. The researcher analyses from the observation recording which has been transcribed. Additionally, interview which has been transcribed is the second analysis.

The purpose of this drawing conclusion is to give the clear the virtualization which type of alternative assessment activity implemented and how the alternative assessment implemented for writing in second semester of industrial engineering at UMG. The conclusion of the result interview with the lecturer give the clearest to understand how the alterative assessment apply for writing in industrial engineering. As Miles and Huberman (1994) told that conclusion are confirmed as the process of analysis.

\section{Discussion}

This study focused on investigating the implementation of alternative assessment for writing skill in second semester of industrial engineering at UMG. Some types of alternative assessment were described by Ercilia (2016) which were portfolios, writing samples, learning logs or journals, conferencing, s-o-s summary, feedback, peer feedback, self- 
assessment, and reflective writing. Observation form was used for finding the types of alternative assessment which were implemented by T1 and T2. And the result showed that both lecturer applied writing sample, conference, and teacherfeedback. Additionally implementation of alternative assessment which were applied by the lecturers could be concluded into some descriptions.

The first was writing sample. The lecturers asked the students to compose sentences as the practice then ask them to compose full text procedure text in order to identify individual writing, so it can be used as tool to reflect their work and as tool to recognize their written work.

The writing product which was used in this present study was composing sentences, memo, and procedure text. Those were the writing product used for implementing writing sample. As Hamayan (1995) told that any writing product could be applied for assessing the learner's language proficiency and learners' progress. The presents study showed that writing sentences were applied first then text about memo and procedure text were applied in order to assess and see the progression in students' writing. Furthermore, the lecturer drilled them in composing sentences in front of the class to make them practice many times for comprehending writing composition. In same line, Swanto and Din (2014) stated that drilling technique affected writing performance which improved the students' English writing performance.

The second type was conference. The lecturer asked the students to discuss about their writing work. After they finish the assignment, then the students face the lecturer to correct together with the lecturer. The students can share their understanding related to their work. When they do not understand, the lecturer helps them by giving clue or explanation. It can be used as tool to assess the students' participant and written work.

The conference in this study was conducted both in whole class and face to face. It was same line with the theory of Brown and Hudson (1998). They stated that conference involved the students to consult related to their own work to the lecturer. So' discussing about the writing work with lecturer or whole class by lecturer's guiding were called conference.

The third type is teacher-feedback. The lecturer applied both feedback written and orally. By feedback, the students can enhance their writing skill since they know their mistakes. After doing the task, the lecturer gave time for the students to share comment related to the students' writing orally and written on the students' writing work.

Additionally, there was previous study about the implementation of teacher feedback in students' writing. It was conducted by Ainiah (2015) which was to describe the implementation of teacher-feedback. This was qualitative research which was found that the teacher implements teacher corrective feedback in the students' writing on two ways. The first was direct corrective feedback. The teacher corrected or revised the students' error by herself directly, from incorrect become the correct one. The second was indirect corrective feedback. The teacher just circles, crosses, puts some error codes, or writes some notes to the students' error.

In the same line, the present study found that teacher-feedback was applied direct and indirect way. The direct way was feedback which was given by writing the correct word on the paper. While indirect way was as giving underline or cross about the error of the words. Furthermore, the finding in the present study applied oral-feedback which was giving comment and correction orally by giving clue related to the students' writing work which was as indirect way for giving feedback to the students. Additionally, the lecturer had to provide feedback to the students in order to motivate them to be better in composing writing. Brookhart (2018) stated that the students could lose motivation for improving writing when they did not receive feedback.

Furthermore, the previous study which was done by Wubshet and Menuta (2015) showed that English teacher did not give equal level in process and product during the assessment. It is contrary with this result of the study which the lecturers let the students to practice writing and also gave space for producing written product. Moreover the lecturer gave some opportunity to the students for producing writing such kind of sentence and text. The lecturers claimed that when the skill was productive such as writing, then the students had to produce writing product. In addition, the students like when composing sentence or text whether in front of the class of on their paper.

To short, in writing skill the students had to get practice in order to comprehend the writing and be more confident for composing writing. After they comprehended then they could compose full text. When the students practice in writing, the lecturer guided them by discussing face to face or in whole class. The feedback had to be given to develop the students' motivation in writing. Because the motivation was high then the students could improve their writing composition and help the students to revise their writing' work.

\section{Conclusion}

The researcher gets some conclusions after analyzing the data. Those conclusions are written to answer the research questions. The first research questions is what is alternative assessment for writing skill implemented in second semester of Industrial Engineering at UMG. It can be concluded that the lecturers applied writing sample, conference, and teacherfeedback. Those are the types of alternative assessment for writing skill which have been implemented by the lecturers. The next research question is how is the implementation of alternative assessment for writing skill in second semester of 
Industrial Engineering at UMG. The implementation of alternative assessment consists of three types. Those are writing sample, conference, and teacher-feedback was applied in various ways. The writing sample used as the practice by composing sentence then composes text to know the progress. The conference can be held in face to face with lecturer and with whole class. Additionally, the feedback can be given during activity and after activity in spoken and written.

\section{References}

Anwar, K., \& Arifani, Y. (2016). Task Based Language Teaching: Development of CALL. International Education Studies, 9(6), 168-183.

Anwar, K. (2016 a). Working with Group-Tasks and Group Cohesiveness. International Education Studies, 9(8), 105.

Anwar, K. (2016 b). Panel Discussion and the Development of Students' Self Confidence. English Language Teaching, 9(4), 224-229.

Ainiah, Nur. 2015. The Implementation of Teacher Corrective Feedback in Students Writing at Senior High School. Thesis. English Department, Education Faculty, University of Muhammadiyah Gresik.

Ary, Donal et.al. 2010. Introduction to Research in Education. The eight edition Wadsworth, Cengage Learning. Canad

Asmara, C. H., Anwar, K., \& Muhammad, R. N. (2016). EFL Learners' Perception toward an Outdoor Learning Program. International Journal of Education \& Literacy Studies, 4(2), 74.

Assessment, Articulation, and Accountability: A Foreign Language Project. Department of Education, Washington, DC. 1999. Guides Classroom Teacher (052) Reports Descriptive (141).

Bennett, R. E., \& Gitomer, D. H. 2009. Transforming K-12 assessment: Integrating accountability testing, formative assessment and professional support. In C. Wyatt-Smith \& J. J. Cumming (Eds.), Educational assessment in the 21 st century. New York, NY: Springer

Berg, Andrew and Pattillo, Catherine. 1999. Are Currency Crises Predictable? A Test. IMF Staff Papers. Vol. 46, No.2

Brookhart, Susan M. 2008. How to give effective feedback to your students. USA.

Association for Supervision and Curriculum Development. Brown, James D and Hudson, Thom. 1998. The Alternative in Language Assessment. TESOL QUARTERLY. Vol 32, no 4

Chapman, C. 1990. Authentic writing assessment: Practical Assessment, Research \& Evaluation

Connors, Robert J. and Andrea A. Lunsford. 1993. Teachers' Rhetorical Comments on Student Papers. College Composition and Communication

Deane, Paul. 2011. Writing Assessment and Cognition. Educational Testing Service. Research Report ETS RR11-1

Dikli, Semire. 2003. Assessment at a distance: Traditional vs. Alternative Assessments. The Turkish Online Journal of Educational Technology. volume 2 Issue 3 Article 2.

Dodge, J. (2009). 25 Quick Formative Assessments for a Differentiated Classroom. U.S.A: Scholastic Inc.

Dhindsa, H., Omar, K., \& Waldrip, B. 2007. Upper Secondary Bruneian Science Students' Perceptions of Assessment. International Journal of Science Education, 29(10)

Ercilia, Cárcamo Díaz Roxana, et. al. 2016. The role of alternative assessment on the writing domain of the english composition courses enrolled in the english teaching bachelor degree at the foreign language department of the university of el salvador. University of El Salvador School of Sciences and Humanities Foreign Language Department, San Salvador, El Salvador. Hamayan, Else V. 1995. Approaches to Alternative Assessment. Annual review of applied linguistics. USA. Cambridge University Press.

Harris, M., \&McCan. 1994. Assessment. Oxford: Heinemann. Heilenman, L.K. 1990. Es ciudad o editorial

Harwell, M.R. 2011. Research design: Qualitative, quantitative, and mixed methods. In C. Conrad \& R.C. Serlin (Eds.), The Sage handbook for research in education: Pursuing ideas as the keystone of exemplary inquiry (Second Edition). Thousand Oaks, CA: Sage

Huot, Brian. 2002. (Re)Articulating Writing Assessment for Teaching and Learning. UTAH STATE UNIVERSITY PRESS. Logan, Utah. Jalizadeh, Kaveh and Dastgoshadeh, Adel. 2011. Role of alternative 
assessment techniques in improvement EFL learners' speaking skill (Iranian EFL setting). International Journal of Asian Social Science. Vol 1, No.2, pp 27-25

Javed, Muhammad et. al. 2013. A Study of Students' Assessment in Writing Skills of the English Language. International Journal of Instruction. Vol.6, No.2

Ketabi, Somaye. 2016. Different methods of assessing writing among EFL teachers in Iran. International Journal of Research Studies in Language Learning. Volume 5 Number 2, 3-15

Kroll, B. (ed.). 1990. Second language writing: Research insights for the classroom. Cambridge: Cambridge University Press

Linn, R. L., \& Miller, M. D. 2005. Measurement and assessment in teaching (9th ed.) Upper Saddle River, NJ: Prentice Hall

Lopes, Lenite Silva. 2015. Alternative assessment of writing in learning English as a foreign language: Analytical scoring and self-assessment. Bridgewater State University, Bridgewater, Massachusetts.

Matsumoto, David. 1999. Culture and self: and empirical assessment of Markus and Kitamaya's theory of independent and interdependent self-construal. Asian Journal of Social Psychology. Volume 2: 289-310.

Milnes, Terry and Cheng, Liying, 2008. Teachers' Assessment of ESL Students in Mainstream Classes: Challenges, Strategies, and Decision-Making. TESL CANADA JOURNAL/REVUE TESL DU CANADA. VOL. 25 , NO 2.

Miles, Matthew B and Huberman, A Michael. 1994. Qualitative Data Analysis second edition. USA. SAGE Publication, Inc.

Mussawy, Sayed Ahmad Javid. 2009. Assessment Practices: Student's and Teachers' Perceptions of Classroom Assessment. Center for International Education at ScholarWorks@UMass Amherst. Paper 9.

Nasri, Nurfaradilla et al. 2010. Teachers' Perception on Alternative Assessment. Procedia Social and Behavioral Sciences 7(C) 37-42.

Nodoushan, Mohammad Ali Salmani. 2014. Assessing Writing: A Review of the Main Trends. STUDIES IN ENGLISH LANGUAGE AND EDUCATION, Volume 1, Number 2.

Nouh, Nowreyah A. Al, Taqi, Hanan A., Kareem, M. Abdul. 2014. EFL Primary School Teacher' Attitudes, knowledge and skill in alternative assessment. International Journal Studies. Vol. 7, no. 5

Paulson, F Leon, Pearl R Paulson, Carol A Mayer. 1991. What makes a portfolio a portfolio?, Educational Leadership, 48 (5), (pp. 60-63)

Puhl, C.A. 1997. Develop, Not Judge: Continuous Assessment in the ESL classroom. Forum Online, 35(2).

Samad, Arshad Abdul. The Use of Portfolio as an Assessment Tool in the Malaysian L2 Classroom. International Journal of English Language Education. Vol. 1, No. 1

Spence, Paul and Liu, Gi-Zen. 2013. Engineering English and the high-tech industry: A case study of an English needs analysis of process integration engineers at a semiconductor manufacturing company in Taiwan. Journal homepage: www.elsevier.com/locate/esp

Swanto, Suyansah and Din, Wardatul A. 2014. Employing Drilling technique in Teaching English Writing Skills to a Group of Rural Malaysian Students. Developing Country Studies. Vol.4, No.14

Tabatataei. 2012. The Effect of Portfolio Assessment Technique on Writing

Performance of EFL Learners. English Language Teaching, 5(5)

Trachsel, Mary. 1992. Institutionalizing Literacy: The Historical Role of College Entrance Examinations in English. Carbondale, IL: SIU Press

Tsui, Amy B.M. and Ng, Maria. 2000. Do Secondary L2 Writers Benefit from Peer Comments? Journal Of Second Language Writing, 9 (2), 147 - 170

Tuan, Luu Trong. 2010. Enhancing EFL Learners' Writing Skill via Journal Writing. English Language Teaching. Vol. 3, No. 3

Wubshet, Hailu and Menuta, Fekede. 2015. Investigation the practice of alternative assessment in english classroom: the case of selected grade nine English teacher assessment practice. International journal of scientific research in education. Vol. 8, no. 4 
Yancey, Kathleen Blake. 1992. Portfolios in the Writing Classroom: An Introduction, ed. Kathleen Blake Yancey. Urbana,IL 